Sviatlana Ahiyevets

\title{
FINANCING PUBLIC HEALTH SERVICES IN THE REPUBLIC OF BELARUS
}

\section{Introduction}

State expenditure is one of the elements of financial public activity. The maintenance, structure and size of state expenditure are defined by problems and requirements expressed in the forecasts of development of a public economy, and specific targets set at a given stage of development. Public health services financing takes an important place in total state expenditure. Therefore, jurisprudence traditionally focuses on the issues of efficiency of providing access to medical resources and the perfection of mechanisms of formation of financial resources in public health services. A search for the effective system of financing of public health services is the State's aim. At present we may talk about two ways of financing of the state system of public health services in the Republic of Belarus: budgetary and off-budget. The basic source of financing of public health services are the means of the state budget allocated according to the specification of budgetary security of expenses on public health services calculated per one inhabitant. Specifications of budgetary security of expenses on public health services are prepared and approved of on statutory basis. In the specification of the budget and in the course of its execution in connection with changes of terms of payment, the prices for the goods and services in the planned assignments are subject to indexation (without actual increase of expenses on public health services organizations).

Off-budget sources of financing of public health services are:

1) receipts from rendered medical services above permitted standard;

2) means from rendered payable services to the population;

3) means allocated with local executive and administrative bodies for the realization of actions that are not set forth in budgetary financing of target programs; 
4) means received on account of reimbursement for treatment of individuals who are trauma victims, suffer from poisoning or diseases connected with manufacturing process;

5) other receipts not contradicting the legislation on legal and natural persons.

All above listed additional financial assets are not taken into consideration in defining the size of assignments from the budget calculated under the specification of budgetary security.

According to Ministry of Health of the Republic of Belarus, in 2007 the share of off-budget means in the total financing amounted to 5,8 \% ${ }^{1}$. Considering the importance of the expenses incurred from the budget for resolving problems and maintaining state functions in the sphere of public health services from a legal point of view, it is necessary to search for the optimum system of financing of the public health services, including redistribution of resources of public health services according to priorities, their more rational use, re-structuring of medical aid volumes at the level of their provision, perfection and improvement of medical aid quality. The problem of fuller satisfaction of the population's requirement for qualified medical aid and the maintenance of its equal availability at all levels of the population should be resolved too.

\section{Basic part}

Budgetary expenses on public health services take a special place in the state expenditure. Health protection and improvement are the most vital needs of an individual. Public health care is understood as a dynamic process of protection and development of biological, physiological and psychological functions of separate individuals, collectives of workers and entire population of the country, the maintenance of optimum work capacity and social activity of people at the maximum life expectancy. Actually, the principle of general availability of medical aid in the Belarus State is provided by the state system of public health services through budgetary financing. With reference to domestic conditions, when there is no system of obligatory medical insurance, the principle of partnership of the state and citizens in medical aid financing is now being realized. Any civilized state bears responsibility for a state of health and sanitary well-being of the citizens as their health is a question of national safety of a country. The analysis of practices of the organizations of public health services in various countries allows to draw a conclusion that there are now three basic models of financing of the system of

1 Пресс-релиз «Об итогах работы органов и учреждений здравоохранения в 2007году и основных направлениях деятельности на 2008 год» // www.minzdrav.by/med/. 
public health services: insurance-based, private and state (budgetary). None of these models are realized in a "pure" form. There is usually a combination of all three ways of financing, with one of them as a prevailing one:

1. The insurance-based system of financing of public health services takes a form of financial resources at the expense of premiums paid by workers and employers with an insignificant financial participation of the state.

2. The private public health services model assumes full absence of the system of obligatory state insurance. The state pays for medical treatment and services of the elderly and other citizens that are not protected by financing from target programs. Basically, medical treatment and services are paid through the system of private insurance.

3. The system of budgetary financing of public health services assumes that the budget becomes a basic source of financing of public health services. Therefore it is not necessary to equate various forms of the state budgetary financing of public health services as they differ depending on a degree of centralization. Budgetary financing can be carried out both by direct state financing and on the basis of special government programs. Direct state financing remains a primary form of the organization of the system of public health services in the Republic of Belarus. A basic organizational and legal form of public health services in the Republic of Belarus is rendering medical and social help at the expense of the means from the state budget, which allows to raise social security of all citizens irrespective of their financial conditions. Within the limits of a given form, financing of official bodies of public health services and their divisions is carried out by the Republic of Belarus according to the Constitution in a form of free medical treatment and services provided for the citizens of the Republic of Belarus as well as the population constantly living in the territory of the Belarus State and migrants.

It should be noticed that apart from the state system of public health services in Byelorussia there is a private system of public health services, which covers all medical organizations and units established by natural persons. Medical services are provided by these organizations on the basis of the conclusion of civil law contracts for rendering medical services. The private system of public health services is of a great value but it does not guarantee social protection for the citizens. This system acts as a means of attraction of additional resources in public health services; it is a part of the financial system of a socially focused market economy where medical services are provided for individuals with high level of income, which allows them to use the option offered by medical institutions and medical services over the guaranteed level. 
Today there are three organizational and legal forms of rendering medical aid in the Republic of Belarus. The basic form providing social security to the population in the sphere of public health services is rendering medical aid at the expense of the means from the state budget by the state organizations of public health services. The independent organizational and legal form is rendering payable kinds of medical aid and services, where medical aid is paid by the citizens from their personal income or from employer's profits. Rendering medical aid at the expense of the means from voluntary medical insurance is also an independent organizational and legal form whose purpose is to strengthen citizens' health by making employers and citizens economically interested in health protection.

In the system of budgetary financing of public health services the budget becomes a basic source of financing of public health services. Therefore it is not necessary to equate other forms of the state budgetary financing as they differ depending on a degree of centralization. Budgetary financing can be carried out both by direct state financing and on the basis of special government programs. Direct state financing is the primary form of the organization of the system of public health services in the Republic of Belarus.

The analysis of the process of transformation in the CIS countries, including Russia, has convincingly shown that transition to medical insurance has caused a set of negative consequences. The Republic of Belarus has kept accessible and free medicine. Official units of public health services perform and maintain the guaranteed volume of free medical aid. Thus according to the legislation socially fair distribution of budgetary funds is carried out. However, public health services appear to depend both on a condition of the state budget, the economic forecast and a condition of public health as a whole. Due to the state budget deficiency, competition and other numerous problems, scheduled means intended for public health services development often appear focused on momentary expediency rather than on long-term interests of business. Therefore, social branches may develop successfully only together with other forms of financing.

Let's consider the features and principles of the organization and functioning of budgetary financing of public health services as its volume makes the basic share of expenses of the state on public health services. It is caused by the fact that, on the one hand, the right to health protection is guaranteed by the Constitution (under the Constitution of the Republic of Belarus, the citizens have the right to free medical treatment and services in official units of public health services). Thus the state is obliged to grant necessary volume of medical aid to each inhabitant in official units of public health services. On the other hand, in the Republic of Belarus two systems of public health services operate: state and private. At the same time the overwhelming majority of stationary (hospitals, clinics, medical centers) and out- 
patient-polyclinic units are state-owned, and their functioning is provided at the expense of budgetary expenses. For this reason, in budgetary functional classification of expenses, public health services financing is defined as an independent section of expenditure of means for the performance of the state functions. Among subsections which concretize a direction of means for the realization of the state activity in the subject area there are: applied scientific research, scientific and technical programs and projects in the field of public health services that are named «other expenses in the field of public health services», «medical aid to the population», «sanitary-andepidemiologic supervision $»^{2}$.

Since 2001, in Belarus, the indicator of the level of the State expenditure on public health services has been defined in relation to the gross domestic product. The consolidated budget of public health services in 2007 amounted to $4,2 \%$ GDP. The specification of budgetary security of expenses on public health services is calculated per one inhabitant ${ }^{3}$. The specification of budgetary security of expenses on public health services calculated per one inhabitant is estimated annually in the budget prepared for a scheduled year and established annually by the Law of the Republic of Belarus "On the Budget of the Republic of Belarus" for a scheduled year ${ }^{4}$.

The specification of budgetary security of expenses on public health services is established for a year without divisions into quarters or months, and it is a basis for defining volumes of financing of expenses on public health services at the expense of the means from the budget for a scheduled year. The specified order of calculation of the specification of budgetary security of the expense on public health services calculated per one inhabitant is then applied.

Ministry of Health of the Republic of Belarus estimates indicators of the specification of budgetary security of expenses on public health services for a fiscal year pursuant to the Law of the Republic of Belarus "On the Budget of the Republic of Belarus" for a scheduled year on the basis of the volume of financing of expenses, taking into account its specification within a year and actual financed expenses spent on middle aged citizens.

Ministry of Health carries out monthly analyses of a course of actual financing of expenses on public health services both in the absolute sum and calculated per

Закон Республики Беларусь от 5 мая 1998г. «О бюджетной классификации Республики Беларусь» №158-3 в ред. от 29 декабря 2006г. №189-3// Национальный реестр правовых актов Республики Беларусь. -2007. №4.

3 Постановление Министерства здравоохранения Республики Беларусь и Министерства финансов Республики Беларусь от 29 сентября 2000 г. об утверждении положения о порядке исчисления норматива бюджетной обеспеченности расходов на здравоохранение в расчете на одного жителя, $\mathrm{N} 40 / 101 / /$ Национальный реестр правовых актов Республики Беларусь. - 2000. №105.

4 Закон Республики Беларусь от 26 декабря 2007г. “О бюджете Республики Беларусь на 2008 год» №303-3 // Национальный реестр правовых актов Республики Беларусь. - 2008. №4. 
middle aged citizens of a given administrative and territorial unit in comparison with the confirmed quarterly list of expenses on the basis of the operative information. The control estimation of a course of financing of expenses on public health services is carried out quarterly and following the results of a year on the basis of data of the official financial reporting.

For 2008 the minimum specification of budgetary security of expenses on public health services per one inhabitant in the Republic of Belarus (taking into account the means for the liquidation of consequences after the accident at the Chernobyl atomic power station) is established at a rate of RUB 503.041.

The order of the use of financial assets of the organizations of public health services is defined by the estimate of expenses on the basis of territorial programs and medical aid volumes.

Realization of expenses of the state budget is based on principles of efficiency and economy. Therefore, the budgetary funds allocated under the estimate of expenses to the organizations of public health services and saved as a result of introducing highly effective and less expensive medical technologies, new forms of work organization and other actions assuring economical use of resources, remain at the disposal of public health services organizations. Saved financial assets are assigned for operational expenditure, strengthening resource base, including purchase of medical equipment, as well as materials stimulating work of medical workers ${ }^{5}$.

The system of financing of public health services in the conditions of creation a socially focused market economy in Byelorussia is based on the following principles.

1. The principle of addressing and a special-purpose character of use of budgetary funds. The specification of budgetary security of expenses on public health services is calculated per one inhabitant.

2. The principle based on a "joint liability" rule. A prominent feature of market economy is an individual's freedom to choose to accept various decisions. Well-being of a person depends on his initiative and activity. Each person is, first of all, responsible for themselves when it comes to a question of insurance against risk of a general character. But there are situations in life when an isolated person is deprived of the joint help of other people and thus his existence may become endangered. Advanced public systems protect individuals in difficult situations regardless of the principle of personal 
responsibility. There are certain social and ethical obligations of a society towards an individual. The "joint liability" principle is one of them.

3. The principle of creation and expansion of organizational forms of the system of public health services. Systems of public health services existing nowadays in developed countries are the results of long-term development. Their formation occurred evolutionary from simple forms and low levels of social safety to more perfect and stronger economic, social and political bases. The increased volumes of state financing followed the growth of economic power of the state.

4. The alternativeness principle in the creation of the system of public health services. This principle is expressed in maneuvering freedom in the creation of the system of public health services on the basis of a combination of its separate components: financing, organizational structures, a group of individuals that are subject to the guaranteed health services, volumes and health services forms.

5. The principle of uniform (general) social partnership. The state develops uniform (general) standards of social protection of the population, provides minimum guarantees in the field of payment, provision of pensions, grants, medical treatment and services, formation and ecological protection to all citizens of the country by the creation of a corresponding legal base.

6. The principle of separation of powers. Financing is carried out on all republican and local levels. On the other hand, it can be carried out by the state and at the level of an enterprise or a private person.

7. The principle of «participation in costs». Financing of certain medical programs is carried out with the assistance of personal means of citizens.

8. The guardianship principle. Financing of medical services at the expense of taxes with orientation to individual needs.

\section{Conclusions}

Thus financial maintenance of the system of public health services is the obligation of the Republic of Belarus. At the same time disproportion between necessary volume and quality of medical aid and available resources for its rendering creates an effective mechanism of financing of public health services at the expense of attracting new sources of financing by the branches whose purpose is not replacement but strengthening of the state guarantees for the provision of medical aid to the citizens. Different variants of the organization of medical aid provided for 
the citizens and organizational and legal forms of financing should assure the most simple and effective way of realization of the right to medical aid, which would enable to provide each citizen with the best possible and rational medical aid. In the Republic of Belarus it is generally possible to present basic sources of financing of public health services as follows: budgetary expenses, voluntary medical insurance, means of natural and legal bodies, medical organizations' own means. 


\section{Streszczenie}

Finansowanie systemu opieki zdrowotnej na Białorusi należy do zadań państwa. Jednocześnie występująca dysproporcja pomiędzy potrzebami co do zakresu i jakości świadczeń zdrowotnych a dostępnymi zasobami, tworzy efektywny mechanizm finansowania opieki zdrowotnej poprzez zaangażowanie nowych instytucji z różnych obszarów, których celem nie jest zastępowanie, ale wzmacnianie państwa przy gwarantowaniu dostarczania usług medycznych obywatelom.

Różne modele organizacji opieki zdrowotnej, organizacyjne i prawne formy finansowania powinny zapewnić najprostszy i najbardziej efektywny sposób realizacji zadań z tego zakresu, który sprawi, że usługi medyczne będą świadczone na najbardziej optymalnym i racjonalnym poziomie. Na Białorusi można wskazać następujące źródła finansowania opieki zdrowotnej: środki budżetu państwa, dobrowolne ubezpieczenia zdrowotne, środki pochodzące od osób fizycznych i prawnych, środki organizacji medycznych. 